AJIT-e: Online Academic Journal of Information Technology
2018-Cilt/Vol: 9-Sayı/Num: 34
DOI: 10.5824/1309-1581.2018.4.009.x
http://www.ajit-e.org/?menu=pages\&p=details_of_article\&id=387

Received : 16.09.2018

\title{
Towards A Supranational Media Theory
}

Fatih ARTUN, PhD Student, Marmara University, Turkey / fatihartun@gmail.com

Sevki ISIKLI, Assoc. Prof. Dr., Marmara University, Turkey /sevki.isikli@marmara.edu.tr

\begin{abstract}
Satellite systems and the Internet have created a significant alternative that undermines the traditional reporting approach and triggered the search for a new order in mass communication. Instant and interactive data transfer systems have transformed local users into global readers and reporters encouraging a trend of democratization relative to freedom of thought and expression. Content providers and distributors in the traditional news industry which is televisions, magazines, radios, newspapers, online platforms, have a wide range of freedom to reach people. Consumers who use interactive mass communication systems have opportunities to interact with the content that is produced in many different centers. However, in the presence of the media defined as a mechanism that manufactures the consent of people for certain ideas, no matter if they are traditional or novel, people sometimes take the position of a buyer or an activist who takes action for a project and sometimes a part of a group of insusceptible people. People think their consent is their freewill without noticing that it is just a product. They feel a sense of gratitude to the ruling elites without noticing that they are the subjects of a social experiment and under the hypnotic influence of the media. Even though the world societies are getting the same content using the same communication technologies thanks to supranational media companies. Particularly because of content created to convey a message, social differences become more explicit and radical rather than the values in common. That's why conflicts are incited. At the heart of the majority of new media organization debates, the existence of this problematic information lies. This article, which has been prepared with an analytical approach based on a literature review, discusses the theoretical conditions and the possibility of a new supranational media structure that world citizens need as a source of information. The philosophical basis of the supranational media ideal in question is at the heart of cosmopolitan individuals and eternal peace ideals of The Universal Declaration of Human Rights. The present media are unable to produce content that doesn't try to convey a message as it positions individuals as "consumers or user" rather than "people". Here, supranational media depicting theoretical conditions doesn't seek profit. It introduces individuals and cultures with their diverse social layers in the consciousness of being a cosmopolitan. Supranational media's output is based on notions like science, rights and freedoms, the earth, coexistence, and "humanity".
\end{abstract}

Keywords: Supranational Media Theory, International Media, World Citizenship, Cosmopolitanism, Informational Supranationalism, Supranational Unions.

\section{Uluslarüstü Bir Medya Teorisine Doğru} oluşturdu, kitle iletişimde yeni düzen arayışın tetikledi. Anlık ve etkileşimli veri aktarımı, bir 
yandan yerel kullanicları küresel okurlara ve muhabirlere dönüştürdü, diğger yandan düşünce ve ifade özgürlüğ̈̈̈nde görece bir demokratikleşme trendi başlattı. Geleneksel medya haber kaynaklarındaki içerik üreticileri ve kanallardaki dağıtıcılar, kullanıcı ve tüketicilerin sahip olmadıkları bir özgürlüğe geniş çapta daime sahip oldular. Fakat etkileşimli kitle iletişim sistemlerini kullanan tüketiciler, bugün çoğu farklı merkezlerde üretilen içeriklerle çok yönlü etkileşim imkanına kavuştular. Bununla birlikte ister geleneksel isterse yeni olsun, belli fikirler için halkın rızasını üreten bir mekanizmaya dönüşen medya karşısında kişiler, bazen bir alıcı, bazen bir proje için harekete geçen bir eylemci, bazen de eylemsizlik halindeki bir kitlenin parçası olma statüsünde bulunur. Kişiler, gösterdikleri rızanın mamül olduğunu fark etmeksizin iradelerini özgür sanırlar; bir sosyal deney alanının denekleri oldukların ve medyanın hipnoz etkisi altında bulundukların fark etmeksizin yönetici elitlere karşı minnet duygusu beslerler. Her ne kadar ulusötesi medya şirketleri sayesinde dünya toplumlar ayn iletişim teknolojilerini kullanarak aynı içeriklere ulaşıllyor olsa da temelde mesaj kaygılı içerikler yüzünden ortak noktalardan ziyade, toplumsal farklhlklar belirginleşir, radikalleşir ve çatışmalar körüklenir. Yeni medya düzeni tartışmalarının çoğunun merkezinde bu hastalıklı enformasyon dolaşım mekanizması yer alır. Literatür taramasına dayah analik bir yaklaşımla hazırlanmış olan bu makalede, dünya vatandaşlarının, yalın enformasyon kaynağı ve kanalları olarak yeni bir uluslar üstü medya yapılanmasına duydukları ihtiyacın teorik koşulları ve imkanı tartışılmaktadır. Söz konusu uluslarüstü medya idealinin felsefi temelleri, kozmopolitan birey ve edebi barış idelerinde, Teilhard De Cardine'in küresel bilinç tezinde veya Insan Haklarn Evrensel Bildirgesi düşüncesinde içkindir. Mevcut medya, bireyleri "insan olarak" değil, "kullanıcı - tüketici olarak" konumlandırdığından "mesaj kaygısız içerik" üretemez durumdadır. Burada teorik koşulları tasvir edilen uluslar üstü medya, kâr amaçı gütmez, çeşitlilik ve zengin katmanlarıla birey ve kültürleri dünyalı olma bilinci çerçevesinde tanıtır. Bilim, hak ve özgürlükler, yeryüzü, birlikte mevcudiyet ve "insanlik" kavramlar etrafinda habercilik yapar.

Anahtar Kelimeler: $\quad$ Uluslarüstü Medya Teorisi, Uluslararası Medya, Ebedi Barış, Dünya Vatandaşlığı, Kozmopolitanizm, Enformasyonel Uluslarüstücülük, Uluslarüstü Birlikler

\section{Introduction: Globalisation and International Organizations}

If Kant offered proposals such as "No State Shall by Force Interfere with the Constitution or Government of Another State, No State Shall Incite to treason in the opposing State, Standing Armies Shall in Time Be Totally Abolished, National Debts Shall Not Be Contracted with a View to the External Friction of States, The Law of World Citizenship Shall Be Limited to Conditions of Universal" in order to obtain eternal peace now, he could not help criticizing this problematic situation that stems from the present media structure. Kant's proposal for "Not Interfere Another State" (Kant, 1991: 346) can be limited to embassy activities and business ventures in other countries in his time. So much so that in the 18th century the media was not a dominant actor with a complex structure, producing inequality, sharing power, promoting cultural and international division. It was largely devoid of molding public opinion (manufacturing consent) and the power to intervene in governance (4th power). Kant has anachronistic reasons for not touching upon the media and communication in establishing a global human unity. However, the situation we have come up with today has developed in a way Kant has never foreseen. There are various statements and strong objections that imply the media structuring is one of the fundamental obstacles to global and eternal peace. In 20th century, McLuhan remarked that mass communication has the 
potential to turn the world into a village and he defined this actual state as a "global village" (McLuhan, 1966). The media, which is growing parallel to the pace of globalization and turning into this new "global village" messenger, seems to fulfill an open space for all voices in the world's political and economic structuring.

\section{Negative Effects of International Mass Communication}

At first glance, sophisticated mass communication channels seem completely appropriate for Kant's civil society ideal. But in reality, an actual opportunity for polyphony could only be created through social media. This corresponds to the second millennium. However, the quality of social media as an independent and free platform is also threatened; its effect is gradually suppressed; its supervision and management are in the hands of old traditional power elites. These platforms, which have the ability to make a voice for everyone, are being brought under control and subjected to pressure, censorship, autocontrol and self-censor to prevent the spread of polyphony. The internet has made communication interactive, easier and quicker, but it could not be safe from the rule of dominant powers, the supervision of gate keeping and the pressure and censorship of political power.

Communication and interaction in McLuhan's global village have turned into a "global network" in the last fifty years. The distance covered by the vehicle speed between the source and the receiver was shortened by the fiber optic cables and satellite systems as the distance has been covered about at speed of light thanks to them; accordingly, the scope and functions of communication have expanded. But while this progress offers opportunities for developed countries, it affected backward countries and countries mostly governed by oppressive rejimes negatively. The citizens of these countries are subject to open or implicit propaganda of both their own regimes and the international media. Technological developments have turned into an actual threat rather than only a disadvantage for the backward countries that are largely deprived of the ability to use global networks and media platforms freely, to produce mass communication technology and to analyze big data circulating or accumulating in the network for its future projections. In terms of having and using communication technologies effectively, the unequal distribution among the citizens of the world has undermined global justice. Today's information revolution has turned the poor-rich balance of the global village against the poor, and has also resulted in other things that have reinforced other parameters of the digital gap.

These imbalances, which were against the backward countries, began to be debated in the 1960s. When the American Communicator Wilbur Schramm stated in 1964 that "The currents of information in the world today are nearly as predictable as thecurrents of air that we call prevailing winds. Frequently an event or a series ofevents disrupts the information flow as a storm disrupts the meteorological chart. Nevertheless, underneath these disruptions are repetitive patterns as regular asthe trade winds" (Schramm, 1964). broadcasting television signals from the sky had not yet begun and the İnternet wasn't an important communication tool. The structure and function of media, which utilizes the spreading Internet and developing mass communication technologies, was discussed at many scientific meetings in the following years. 
UNESCO, a supranational organization, succeeded in putting a convention entitled "Convention on the Protection and Promotion of the Cultural Expressions" into action at one of the NWICO (New World Information and Communication Order) meetings in Paris in 2005. But the United States of America (USA), which owns a large majority of the international media companies, did not support this convention. Despite the fact that in 1979 the New World Information and Communication Order (NWICO), which was recognized as the first organization of its kind led by UNESCO, took its recommendation to remove the imbalances in communication tools and news circulation, it couldn't put it into practice. Tomlinson argued that this showed how far a supranational organization could go. He stated that the debate was "highly circumscribed and ultimately limited by the existing distribution of global economic power" (Tomlinson, 1991).

The world has witnessed the flow of media content from the developed countries to the underdeveloped countries during the last two centuries. The development of communication technologies has made this situation even more dramatic. The efforts of supranational institutions such as UNESCO have not, unfortunately, contributed so far to the establishment of a supranational media organ and the new media order. Countries that have succeeded in establishing considerable supranational associations about politics and economics are unable to make a consensus on establishing a supranational union to regulate the flow of information or they don't do this on purpose. However, the need for supranational institutions is clearly felt on a global scale. For instance;

i. Kant (1793) expressed the need for a federation in accordance with international law, drawing attention to the helplessness the society feels.

ii. Einstein (2002) stated that only a supranational organization could prevent the danger of World War III, which would seriously jeopardize the humanity.

iii. In accordance with the Schuman Declaration (1950), which is the basis of the European Union, supranational institutions about politics, law and economics have been gradually established and are still being established.

However, the demand for a supranational organization, which will serve the common interests of world citizens, will broadcast, publish or post with the aim of raising awareness of being a cosmopolitan hasn't been voiced until now even though it is really needed. Therefore, a global organization such as UNESCO and WHO has not been established, whether under the umbrella of UN or not.

\section{Use Of Media Power for The Common Good}

The media has been charged with molding public opinion, as it has the power of doing so, and convincing the public. Molding public opinion, which is one of the main functions and purposes of establisment and performance of the media, means organizing public in a certain topic, making people ready to accept it cognitively and creating symphaty for both previous and following ideas. There is a lot of research and practice about the fact that mass communication and the media have the power of doing that. Cannot the media, which is 
able to convince the public, be used to serve the common interests of the humanity? The search for supranational media is the actualization of this possibility on behalf of humanity.

Mass communication and media, which delays the use of information and knowledge to inform and enlighten people, now stand out as a propaganda tool and consent manufacturing mechanism. Evaluating international collaborations and associations among the media companies that began in the late 19th century in the context of the hegemony of global powers ends up with fruitful results. This wave of associating media companies is occurring among a small number of media organizations with great economic and cultural power in their countries and this leads to oligopolistic control of the Transnational Media Organizations (Warf, 2007). The international media empires created through associations have advanced technologies such as television broadcasts, satellite technologies, internet technologies and the next generation television platforms for the distribution and consumption of content. They deliver multimedia content such as news, music, movies, and audio to the whole world easily. Thus, they are engaged in an uninterrupted broadcasting activity to infuse the public or political secret agendas and the explicit or implicit messages of the dominant political and oligopoly power into the public. At this point, the natural and compulsory need for supranational media structuring, which will not deprive both the individuals and the societies of this content, will not regard individuals and societies as "social experimental subjects" and will regard them as "world citizens" keeping the idea of "informational supranationalism" in mind, emerges automatically.

\section{Ontological Conditions of International Media}

Centuries after the publication of the first journal in history, the communication channels were completely changed in terms of technique and content when the first radio signals were resolved by the receivers and turned into sound almost simultaneously. On 19th century, signals became wireless (Hong, 2001) transcended borders, including iron ties between countries and physical barriers such as hard trade walls, using infinite space. Historically, electromagnetic waves, which fill the atmosphere surrounding the earth, image-bearing signals and cables on the earth have quickly become significant means of information flow. With the addition of image signals to the transmission of sound, television became the most effective means of mass communication. When CNN International, the world's first news television, was founded by Ted Turner in Atlanta on June 1, 1980, there was still a cold war period in the bipolar world (Friedberg, 2004). This new news channel, expanding its domain worldwide, has become prominent all over the world in 10 years and people have reached the publications of this television due to its small size satellite antennas. It is absurd to talk about the imperialism-communism war today, but channels like CNN still continue to tell the world about Western culture and civilization.

\section{Two Valued Logic: Basis for The Conflict}

Osama bin Laden became a significant name spoken of all around the world after the Twin Towers of the World Trade Center in the United States were attacked on September 11, 2001 and his broadcast on Al Jazeera from Quatar, an Arabic news channel, attracted the attentions of even the people living in different places and speaking different languages, 
thanks to satellite technology. Especially after September 11, Al Jazeera's method of commenting and publishing news, which is totally different from the American approach, was shocking. Al Jazeera's publications were argued by media associations identified with international journalism until then, claiming that they did not comply with publishing ethics. The understanding of international television reporting, represented by CNN International, has been shaped mainly on the basis of Western values and approaches until the turn of $\mathrm{Al}$ Jazeera's publications, and criticism of the publications has been avoided within the framework of freedom of press and freedom of obtaining information. Edward Said, an Arab-American thinker, explains his criticism of imperialism contrasting East and West:

"The worst and most paradoxical gift of imperialism is to allow people to believe that they are only, mainly, exclusively, White or Black, or Western or Oriental"' (Said, 2004).

The dominance of these binary oppositions logic is still valid in the editorial approach of the preparation of international media content.

Most of the East-related news from international channels of Western origin is related to violence, war, conflict or migration, which justifies Said. To distinguish the world as east and west is a habit of the Age of Enlightenment, whose origins are based on the two precious statements of Aristotle's logic. Enlightened European intellectuals divided the world into two regions, "East-West". This division has served as a strategic tactic for the West's struggle with the East. East and West were positioned as two opposing sides. The West and Western values were thought to be superior to the East and Eastern values. As Hobson (2004) phrases, the West was imagined as a blessed civilization with unique virtues:

"The Dynamic West: Inventive, rational, scientific, disciplined, Independent, functional, free, democratic, tolerant, honest, civilised, morally and economically progressive".

The East was seen as the functional other of the West. The West could see itself more clearly comparing itself to the East. The qualities of the East as the opposite other are directly derived from the two valued logic:

"The Unchanging East: Imitative, ignorant, passive, irrational, lazy, corrupt, savagebarbaric, morally regressive and economically stagnant".

The East, which is the object of knowledge in today's international media, is judged by the same "prejudices". In the news, movies and Internet content transmitted by the Western media, primarily to the Western society and other countries, the East is still being perceived and presented with this opposite status. This approach, which emanates from the two valued logic of Aristotelianism, is something polarizing by nature. The Western media language, which is democratic and invaluable in its own right, still maintains its classical logical reasoning when it comes to the East, and this is deeply strengthened from time to time. The latest example is Samuel Huntington's civilization conflict theory (Huntington, 1993).

\section{The Case Study: Al Jazeera}


The East started to appear in the global media as an actor when Al Jazera began broadcasting in Qatar in 1996. Al Jazeera was initially praised as a television channel "against the media imperialism of the West" (Boyd-Barret \& Xie 2008), although it was criticized extensively afterwards. Western countries and their media fully understood Al Jazeera due to its interviews with Osama bin Laden and Saddam Hussein. American media and politicians blamed Al Jazeera, who broadcasts the tapes of Osama bin Laden, for "making propaganda of terrorism" but while doing so, they didn't need to question their open or secret relations with the US Army. Al Jazeera was accused of "not being a true journalist" during the Afghanistan war. Colin Powell, US Secretary of State during that period, personally asked Al Tani, the Emir of Quatar whom Powel talked face to face with on 3 October 2001, to restrain Al Jazeera because it is unbalanced and encourages anti-American statement (Mahajan, 2002).

As a Eastern media Al Jazeera mainly covered Middle East in the news. It carried the victims of the war, the names targeted by the Western public and the civilian casualties on the screen, unlike the Western media. This kind of reporting made Al Jazeera more visible in the short run, but it also started to become a target. Shortly after the US occupied Afghanistan, Al Jazeera's office in Kabul was bombed, and the reporter Sami El Hajj was caught by US troops and imprisoned at the Guantanamo Base for being accused of "terrorism" (Al Cattori, 2009).

Robert Fisk explains why while America was pleased with Al Jazeera's publications in the beginning, it turned it into a target afterwards: "America supported the channel until it became too free "(Fisk, 2001).In fact, Al Jazeera's approach to journalism in an unusual way could be regarded as a balancing factor against the alienation approach of the Western media, but it didn't. This tension between Al Jazeera and the West and the media is manifested in the following verses of Kipling's poem entitled "The Ballad of East and West"

"East is East, and West is West, and never the twain shall meet, Till Earth and Sky stand presently at God's great Judgment seat" (Kipling, 2000).

Today's international media continues to reflect the East and the West as totally separate units on the basis of countries, cultures, nations, states and societies and this has become a pattern for them. But Kipling declares that this discriminatory, divisive, and alienating illness is not insoluable, and he thinks there is a solution although it is difficult to actualise. In the following verses of his poem he says:

"But there is neither East nor West, Border, nor Breed, nor Birth When two strong men stand face to face, though they come from the ends of the earth!"' (Kipling, 2000).

Without entirely relying on this messianic hope, we can get rid of these divisions, which don't inherently exist on earth as the earth is an indivisable whole, starting with getting rid of the elements that promote discrimination. A supranational media to be established can present valuable or fuzzy reasoning practices as an alternative to two-valued reasoning 
habits. The distinctions in this global measure, opposed to each other, suggest the urgency of a supranational media structure capable of representing the whole earth.

\section{Too Far From the Search of Common Good}

Western civilization, which rejects discrimination in its own societies and establishes supervisory mechanisms for all kinds of discriminatory activities, sees discriminatory activity as a natural right, in other societies and doesn't want to be in search of a mechanism that will overcome these obstacles to the global union, at least in the media field. Today, there is no structure or control mechanism to control Qatar's Al Jazeera or the United States' $\mathrm{CNN}$. Supervision and control are left to in-house initiative and mercy. International media companies have their own internal regulations and publication ethics, committed to "independent" activities. But their multinational structures make it difficult to identify them with a nationalist identity. The identity of the society and civilization they belong to damages the ideal of world citizenship. Moreover, in political agreements and alliances, where it is often difficult to prove one's innocence, they broadcast under the influence of their own countries and their economic interests rather than the common interests of mankind or common good. Other concerns, such as reaching news sources, having content distribution, getting operating permits and ensuring the safety of employees, which affect broadcasting activities, do not allow international media companies to be the common voice of the humanity.

\section{The Concepts of International and Supranational}

For the first time, Jeremy Bentham used the concept of international in his book "An Introduction to the Principles of Morals and Legislation" published in 1789, in the context of law. In this book, he explains why he uses the term "international law" instead of "national law": Behaviors can be divided in terms of "the political nature of the individuals who are the subjects of the law". In this case, individuals may be subject to the same state or separate states. Domestic law is required for the same state, and international law is required for separate states (Bentham, 1970). The term "international," which was used to describe international law, began to be used in political and commercial relations, afterwards. Today, political, commercial, cultural and even religious relations among countries are defined as international.

The concept "supranational" is usually used by political scientists to mean "a common decision-making mechanism or unity". Institutions or states that are members of such an organization endeavor to reach a common ground by sacrificing their national interests. The supranational structuring came to the fore with the Schuman Declaration, the basis of the European Union (Schuman, 1950). The first supranational structures based on the Schuman Declaration were established by international agreements in the non-communist bloc of Europe. The Benelux Customs Union, the Organization for European Economic Co-operative (OEEC), the European Payment Union (OEEC), and military institutions like the Western European Union, as well as the European Council in Strazburg are first organizations close to the ideals of supranationalism. 
Supranational structures are established by an international agreement. The nationalities of these institutions are legally abolished. The international institutions established by international bodies are governed by the rules set by international law and founding treaties. The supranational institutions in which the sovereignty rights of the founders or members are determined and some of them are transferred to the organization have connective principles for all members. Robertson (1957) uses the expression "over all individuals and states" to explain what the concept of supranationalism really is.

The concept of supranationalism is discussed, in terms of law, in the context of institutional supranationalism and normative supranationalism. According to Weiler, institutional supranationalism is the institutional framework of a decision-making process that is eventually enacted, where the priorities of communities that are members of supranational structure are discussed and formulated. Normative supranationalism is the principle in which community norms are superior to national norms, supranational law is both applicable and superior to national laws (Weiler, 1981).

\section{Ethical Dilemma of International Media}

Today, modern democracies and the international and supranational structures formed by these democracies are responsible for convincing the public for their actions. Individuals and the society they live in become a part of a decision and approval mechanism in matters directly related to them, being exposed to the information contained on the media. While a common idea is being formed in the public opinion due to mass media, individuals generally prefer to adopt one of the generally accepted ideas rather than expressing their own ideas. According to the theory that is given the name "spiral of silence" by Neumann, for individuals the desire not to be isolated is more important than "personal decisions". Otherwise, individuals would not be able to integrate into society sufficiently well (Noelle(Neumann, 1974). Individuals who can not express themselves because of the fear of being isolated from society and thus become dumb in society can not declare another opinion but repeat the messages of the media, in time.

It is observed that citizens of the world are clearly forced to develop a personal opinion and collective conscience about global issues, under the influence of the international media. However, "active and participating citizens" rather than "silent individuals" can create worldly consciousness. Moreover, the goal of the international media is communities and societies rather than individuals, in direct proportion to their excessive power. This mechanism suppresses not only individuals but also societies; collects both the consent of individuals and societies. It produces content and conveys it to the world for their consumption. It triggers the fear of loneliness and threatens the rest of the world of "being lonely in the international society." In this sense, international media structures in fact, lack in ethical ground. Chomsky and Herman also declare the absence of this ethical ground in an assessment of the media's secret function in adopting and approving an idea in society:

"Societal purpose of the media is to inculcate and defend the economic, social, and political agenda of privileged groups that dominate the domestic society and the state" (Chomsky \& Herman: 1998:298). 
Today the international media fulfills the same function on the international communities. The freedom to express opinions and receive information, the responsibility to clarify ideas and to keep the communities informed of events remains the main business objective in the institutional principles of national and international media organizations. But their discourse and actions are affected negatively by imperial aims. The cooperation of imperialism and the media has been the subject of many debates. Tomlinson, for example, refers to a cultural imperialism that advances from the general to the specific, and he writes about the relationship between cultural imperialism and the media:

"It is tempting to see the media as the central cultural reference point of modern Western capitalism. Cultural imperialism might be seen to centre on the media in two ways: either as the dominance of one culture's media over another, or as the gloabal spread of 'mass-mediated culture' as such" (Tomlinson 1991).

Tomlinson's words are a defense of the media imperialism with an egalitarian approach rather than a criticism. According to him, direct imperialization has always existed in history. Indirect "cultural imperialism" is usually a defense of an authentic culture. It is a fact that imperialism is constantly coming from the West. This fact has justified grounds. Western media organizations have the capital, experience, and infrastructure necessary for the production and use of mass media. It was not possible for the media of the backward Eastern countries to respond proportionally to Western cultural imperialism. In terms of competition, it is seen that the Western media violated fair competition conditions. Therefore, supranational media to be established should promote the cultural heritage of the world, not cultural imperialism.

\section{International Media as a Carrier of the Effects of Globalization}

International integration processes have increased the interdependence level of societies. Philippe de Lombaerdei (2008) defines globalization as "interdependence of cultural, economic and political factors". In the light of the factors mentioned, it is becoming almost meaningless to imagine a global integration or think about international relations if the international media is ignored. Most of the definitions of globalization are equally positive for the members of the global world. But the truth is clearly stated in the following definition of Pieterse:

"The most common interpretations of globalization are the idea that the world is becoming more uniform and standardized through a technological, commercial and cultural synchronization emanating from the West, and that globalization is tied up with modernity" (Pieterse 1994).

When the mutual interaction in a globalized world is in question, it is unreasonable to expect the parties to be influenced by each other equally, especially when the economical and technological power of the West is taken into consideration. Western-affiliated 
companies, monopolising international media and mass communication technologies, praise globalization and its advantages and interpret the content they produce with a Western viewpoint. For underdeveloped or undeveloped countries, it is still possible, at the theoretical level, to come through passive state or produce and distribute competitive content but it is almost impossible in practice. As Doreen Massey (1994) says, there is a "power geometry" here; it is necessary to divide the parties in the globalization process into "winners and losers" or "globalizers and globalized".

\section{Transition from Commodity Imperialism to Information Imperialism}

The global media, which has an economic power incomparable to local and national media, also plays an active role in world politics. Normally, it can be expected that democratic countries are disturbed by the formative effect of the international media shaping public opinion. But when the capital-state-power associations are considered together, enough evidence can be found that these mass media companies, which travel the world without a "visa" represent a new generation of colonialist mindset. The raw data gathered from the world's underdeveloped regions are transformed into finished goods by these news companies and they are imported or exported being loaded onto 21st century colonial ship just like discs, virtual environments, videocassettes, compact discs (CDs), or memory cards. This data, which is processed in the studios of large and showy plazas and computer environments, is conveyed to the relevant regions of the world. It seems as if there is a flow of news between the East and the West, but this flow is actually one-sided and is generally in favour of the West. At first, the advertisements come from Western countries, but in the long run, the consumer countries that are exposed to cultural colonization are to blame. The only thing that changes is the colonial tools that have been used in recent years to bring the wealth of the East to the West. Today, the media is carrying the information and knowledge of the West to the East. The type of exploitation has changed, but the exploiter and exploited have not changed. Commodity imperialism has evolved into information imperialism.

\section{Media Impacts on the Globalization of Local Issues}

International media have an important side effect that is not easily noticed at first: the globalization of local social problems. As the media recently moved away from locality and transformed into a global agent, some related problems were easily able to spread, and social conflicts, migration movements, violent incidents and cultural problems increased to a great extent. The power of national and international media to manipulate the events, to form public opinion and to convince the masses of making wars and invading places by directing them with perception operations has led to major disasters in periods of time that are not very long.

There is not a control mechanism that will balance and control the media, which is a really effective weapon that shapes world, both legally and morally. In this respect, while the media is a respectable means of liberation in terms of providing the flow of information, which is its main reason of being, it is in the position of an unpredictable "global village's idiot" in terms of language and editorial viewpoint. Is it right to isolate this idiot from the village or put the village in quarantine? As both of them create pressure and censonship in 
the long run, Hermes (Martin, 2018), known as the master of wisdom and messenger of the Ancient Greek and Egyptian gods, is needed in the global village. Hermes will balance the idiot of the global village, and make it more controlled and the subject of wisdom in progress of time, utilising his own wisdom.

\section{Manufacturing Consent and Proxy Wars}

The concept of "manufacturing consent", which means convincing the public in a certain issue, was used by Walter Lippman (1922) for the first time. The use of the media for these purposes was further deepened at the theoretical level by Noam Chomsky and Edward Herman. Chomsky, took the concept in question in point of the efforts of the states to convince the people, in his book "Manufacturing Consent: Economic Policy of Mass Communication (1998)". According to Chomsky, "manufacturing consent" is basically based on the media "as a means of convincing the public to do something they do not want by applying new methods of propaganda" rather than "as a means of providing information and knowledge". In today's world, where political authorities delegate "duties, not powers" in national and international relations, the responsibility of manufacturing consent is given to the media. In the proxy wars, the duties began to be given to third party elements. Proxy wars, excluding the media, began to appear as a preference and an important strategy in interstate relations. Konyukhovsky defines proxy war as a war that is made by someone else (through representatives) directly or indirectly in behalf of another (Konyukhovskiy, 2018). From the Vietnam War to the intervention of Afghanistan by many countries, especially the USA, and from the conflict in Ukraine to the Syrian civil war, Proxy wars directly took the place of military conflicts. While proxy forces, assumed mostly by organizations or local militias and left to its fate when they are not needed, bear the consequences of the war they are in, the media, which is the means of molding public opinion and retaining informational power, is able to abstract itself from war and destruction.

\section{Trend of Internationalization and Problem of Representation in the Media}

Globalizers of the trend of globalization have set to establish international media structures. Besides Al Jazeera, which appeal to the Arabs, they established Press TV in Iran, Russia Today in Russia, France 24 in France, DW in Germany, TRT World in Turkey, CCTV in China, Sky News Arabia in the United Arab Emirates and EuroNews in the EU. All of them have targeted international arenas after CNN International. Particularly, the reduction of the cost of satellites and professional broadcast technologies has made it easier to increase the number of channels. The aim of these new international structures, which often mimic the technical infrastructure and content production techniques of British and American companies, is not to derive profit but to break the Western hegemony that leads to one-way information flow and to be the voice of countries or regions. They are in direct relationship with the political governments of their countries. One exception to this happened recently. The tension between US President Donald Trump and CNN International has continued on live social media platforms, live broadcasts and interviews for some time. President Trump accused CNN of making "fake news". He wrote on Twitter: 
“Donald J. Trump (realDonaldTrump): @FoxNews is MUCH more important in the United States than CNN, but outside of the U.S., CNN International is still a major source of (Fake) news, and they represent our Nation to the WORLD very poorly. The outside world does not see the truth from them!" (Trump, 2017).

This accusation, which confirmed CNN International's international support for the United States, was responded to via the same channel:

“CNN Communications (CNNPR): It's not CNN's job to represent the U.S to the world. That's yours. Our job is to report the news. \#FactsFirst" (CNN, 2017).

CNN's answer, "Our job is to make news" did not sound realistic since this answer was not enough to get it out of policy concerns and the "mechanism of manufacturing consent". While the US community was discussing the international media, international journalism, which was actually ongoing, did not stop at all. In discussions, the need of the citizens of the world for reliable information is brought forward and mass communication, which had legitimacy and even gained symphaty with the promise of meeting the need, has been criticized for turning into a propaganda rather than being a promise. Al Jazeera, based in Qatar, quickly became the channel that was followed most in the region. The channel's offices in Sudan, Israel, Maldives and Egypt were raided by the police or closed down because of the news and documents during the Arab Spring (Press, 2011).

Unions, regulations or declarations established to increase the functioning of the media and to achieve a consensus on ethical principles have been establised to reinforce the sovereignty of states, not for the sake of cosmopolitan citizenship and human rights. At the NWICO meeting, assembled in 1972 for the first time, the relationship between globalization and media was strongly emphasized for the first time in the declaration, titled "Guiding Relations for the Use of Satellite Broadcasts for Free Flow of Information, Dissemination of Education and Cultural Change". In the Mezkur Declaration, the delivery of publications to other countries without prior permission was defined as a threat (UNESCO, 1973). However, like many other declarations of UN organizations, it has not been put into practice. According to Asamoah, who evaluates the meetings and declarations of NWICO, held in Geneva in 1962 to make decisions on radio frequency allocation, although the declarations of such kind, under the leadership of the UN, are remarkable as a natural expression of "opinio juris nationum" ("nations' view of the law") it does not give rise to international laws which require liability. It will be able to have a binding force on a number of state levels with the principle of goodwill (Asamoah, 1966).

\section{The Transformation of Goal into Tool and the Mechanism of Self Defense for Individuals}

Although the media is pressured by political and economic centers of power in some cases, it is often ready to be a propaganda tool. In fact, the democratic and legitimate basis of the media is human rights in the form of "information and self-expression". This right also gives a natural mission to the media: transmission of information. This initial "goal" has 
become a "tool" under the influence of international politics, technological progress and globalization. Individuals are passive elements of these discussions; they are excluded from discussions as content consumers. States and notable equity companies can directly influence the content of the media and intervene in it from time to time; so it can be protected against the influence of media by regulations structures such as U.S's The Federal Communications Commission (FCC, 2018).

But any mechanism that protects the individual can not go beyond media literacy at the simple level. The mechanism presented for the individual to use is in the form of self-control. It is like being a conscious news follower or unfollower. Punishing the media by not following it is a kind of Buddhist reaction: retire into your shell, abandon it and do not care! The method of imposing sanctions by ignoring causes the individual to deprive himself of the information and punish him/ herself. Actions such as not to follow or not to watch also limit the individual's right to receive information; when s/he does so, s/he also punishes him/ herself. Saying "do not follow if you do not like it!" means forcing people not to join the world through information and expression. However, as cybernetic organisms, people can not live a balanced and optimal life without being aware of the world. Saying, "abandon it!" is the same as inviting someone to live a low-quality life. The individual who abandons the media can not be a citizen of the world and relinquishes the right to be informed.

Toussaint (1992) compared the new media to the "Trojan horse" by referring to the fact that the Internet has made the individual's private life public, when it had just emerged. In time, computers, tablets, cell phones, smart glasses and watches became more and more similar to the trojan horse, which suddenly reveals the private information of the individual. Especially the Internet and mobile technology have turned into the extension of individuals like limbs. The need for a "World Media" to ensure that everyone has the right to communicate and get information when they are so close to the personal means of communication tools is a reality for us.

\section{Diogenes, Kant and Derrida: Cosmopolitans, Eternal Peace, and Hospitality}

Diogenes of Sinope was a wise man who lived in the Arcaic Age during the times when philosophy was guiding real life. He is best known by the sentence "you can step aside a little so as not to keep the sunshine from me", in response to Alexander the Great, who wants to do him a favour saying "is there anything I can do for you?" The wisdom of Diogenes was not limited to this. One day, those who saw him wondering about town in broad daylight with a lantern asked him why he was behaving in such a manner. He declared "I am looking for goodness". Some other day he answered those who asked him where he was from saying "I am a citizen of the world" (Laetrius, 1895).

Diogenes' cosmopolitan response can be thought as a light in search of supranational media. It may be expected that power holders should not overshadow the media in the way of reaching the world citizenship ideal of free individuals. The cosmopolitanism of Diogenes must be considered together with the interpretation that Deridda brings to "hospitality" stating "we are concerned here not with philanthrophy but with right" (Derrida, 2000a: 3). 
Kant argued that the establishment of a federation based on international law became campulsory, drawing attention to the societies in despair (Kant, 1793: 311). The supranational media steps on philosophical grounds with the ideals of "world citizenship (cosmopolitan)" and "eternal peace" borrowed from Diogenes and Kant. The conditions of world peace are accompanied by the conditions of world citizenship. A cosmopolitan is the one who does not feel s/he belongs to a certain time, a state, a culture or a society, but feels s/he belongs totally to the world, and sees every part of the world as his home. A cosmopolitan makes sentences just like the ones in Barış Manço's song (1993) who is a turkish singer, which has the same name:

"My hometown buddy, where is hometown?

I told you that the world is hometown" (Trans. Altan, 1999).

The supranational media plays an irreducible and nonassignable role in the actualization of the ideal of cosmopolitanism and eternal peace. The humanity has the right of selfexpression and freedom as well as human beings.

\section{The Structure and Functioning of the Supranational Media Organization}

Only the UN, which itself has a supranational structure, can guide the supranational media structure. The "International Media Organization", which can be established with the participation of all countries, is a structure that can not be prosecuted, threatened or constrained because of the humanistic news that provides information flow without any local, national and international obstacles both in the time of war and peace. The people in charge of creating, selecting and distributing the content in the media channels, operated by this supranational media organization, are selected among distinguished journalists with the participation of all the states in the world. This duty, which they perform for a certain period of time has the highest quality of service for media members.

The functioning of an uninterrupted and efficient supranational media channel can only be made possible by artificial intelligence. Both the information collected from local and national channels and the flow of content produced by the supranational media channels themselves, are carried out by artificial intelligence machines, in accordance with legal protocols, without involving human subjectivity. Discriminatory preferences caused by individuals who can not be completely isolated from their cultural codes can be avoided. Individual-focused hesitations, prejudices, weaknesses, tendencies, and discrimination based on religion, language, and race are eliminated or deactivated by the artificial intelligence unit. Postmodern digital cosmopolitans, who are volunteer users of the supranational media channel, interact with artificial intelligence. Thus, the state propaganda is freed from its passive position in the presence of social oppression, cultural imperialism, economic interest, prohibition and censorship, and participates in the free supranational communication network. The rights of a digital cosmopolitan user are guaranteed both by "supranational law" and "informational supranationalism". When the structural and functional characteristics are taken into consideration, supranational media is: 
A non-profit media structure that generates and distributes information and knowledge about human heritage and values, is open to all societies in the world, without the restriction of any race, religion, language and geographical region and can not be subjected to any pressure.

Undoubtedly, the international media has a global influence that can reach any kind of information and knowledge. It is purified and protected from the influence of all political and economic forces that demand the consent of the people. It does not have the intention of convincing or directing anyone. It also does not aim to end wars, internal conflicts, economic crises and migration movements. Instead, it carries every kind of human condition, with all its simplicity, to the digital cosmopolitans as precisely as possible, by avoiding commenting. Cosmopolitan people who comprehend international media content can decide for themselves whether or not to act. Cosmopolitans do not need mediatical persuasion, it is their right not to be exposed to it. Access to content and content itself is free. Supranational media provides accessible data for everyone, anywhere and at any time. But the cosmopolitans' interaction with the content is limited. They cannot make changes in the content. If they wish, they can interpret and discuss this data in their own private channels, but they cannot upload content or direct it there.

\section{Main Characteristics of the Supranational Media}

The supranational media is an independent and non-profit media structure that produces and shares content only about being an earthperson and humanity. If we meet potential Martians in the future one day, we should have a World Media against Mars Media. Some predicted characteristics of the supranational media are:

i. Supranationality: It is established when one of the supranational institutions or countries that are members of all the supranational institutions come together. All member societies adhere to the institutional agreement. The internal law of the institiution is a "sui generis" law. Its owner is the people of the whole world.

ii. Rightousness: The data about the truth is prepared as not interfered and uncensored information.

iii. Freedom: All societies have a free working environment for the supranational media in their own countries.

iv. Objectivity: It treats all the ideologies, ideas, thoughts, attitudes and behaviors equally.

v. Being Non-profit: It does not seek profit. It is funded by the UN. Its expenses are open to inspection. 
vi. Power of Representation: Representatives from all countries and societies are involved in the management, operation and production phase. Those who work in this organization are selected from among the names recommended by each state, after education.

vii. Digital: Internet networks and artificial intelligence are used in the distribution process of the content.

viii. Responsibility: Its responsibility is not shaping the individual and society but creating awareness of humanity and informing people.

ix. Democratic Structure and Management: The management of the International Media Organization is largely related to corporate governance, rather than content management and follow the principle of democratic transparency.

x. Accountability: It is obliged to account for people's demands and accusations.

xi. Immunity: No local court or authority can judge a supranational media worker for his professional activities.

\section{Informational Supranationalism and New Digital Media}

Informational supranationalism is the basic philosophy of supranational media, which can be established by the combination of supranational institutions or political managements representing countries. According to Boyd-Barrett, media imperialism is nourished by the imbalances in the media between countries (Boyd-Barrett, 1977). This approach is associated with the colonization of countries that lack sufficient military, political and economic power and cultural imperialism, during the political and economic imperialism process, and it presents a projection for today. Colonization and imperialism, which started with geographical discoveries, continue with the media imperialism in the cultural level. Huntington explains the struggle of global politics in his thesis on the conflict between civilizations:

"For a century and a half after the emergence of the modern international system with the Peace of Westphalia, the conflicts of the Western world were largely among princes--emperors, absolute monarchs and constitutional monarchs attempting to expand their bureaucracies, their armies, their mercantilist economic strength and, most important, the territory they ruled. In the process they created nation states, and beginning with the French Revolution the principal lines of conflict were between nations rather than princes" (Huntington, 1993). 
The gigantic trenches the ones who administrate, supply and expropriation of mass communication technologies put between civilizations seem as if they can be overcome by the new media, but they continue to drift toward counter poles as the civilizations become closer to each other and they continue to conflict from time to time. Responding the question "does conflict come from the nature of civilizations, or why are they in conflict?" with the answer "because they want to conflict." is the same with not giving an answer. Digital mass media and new media have increased the interaction between individuals and societies, and people have had the opportunity to get to know each other more closely. The distinctions that make things what they are, are made open to conflict by the concerns in question and this brings about the postponement of the common points and the ideal of eternal peace.

There is no doubt that the distinctions between societies were also accepted as differences in the past but these mostly local values weren't on the agenda and were being exaggerated. The expressions about these distinctions remained at local level. Discriminatory expressions in today's new media order can quickly spread to the world if supported by the power elites fostered by discrimination. In traditional media, values and practices of civilizations were spread from top to bottom, by an elite group trained in the West. The Internet-based new media practices have led to a radical differentiation in form and content during cultural diffusion. Now, ordinary people who have access to information at the level of western standards without going to the West have begun to introduce Western values to local people. Traditional, nationalist and radical ideas had the opportunity to encounter civilization. This kind of a meeting, which did not last very long, has laid the foundations of today's conflicts. Behind many ongoing and past conflicts, ethnic, religious and sectarian differences lie, which confirms Huntington logically. The evaluation of Postman on the advantages and disadvantages of technological developments is both ironic and real.

"There are, as it were, winners and losers. It is both puzzling and poignant that on many occasions the losers, out of ignorance, have actually cheered the winners, and some still do" (Postman, 1993).

As the individual is interested in perception, molders of public opinion concentrate on actions. Actions of Internet users can be predicted, directed and created from the beginning. All of these happen, without being noticed, through the Internet-based communication technologies that people use voluntarily. The social media environments where billions of people like, share, comment on, or participate in surveys made it possible to instantly follow the attitude the public( as users)develop towards a certain issue. Based on the correlation between attitudes and behavior, big data analytics that predict how users will respond to the next message were developed. The developers are now the new generation of agents who serve the old sovereign powers or they have same purposes. As a result, social media was made ready to become a "social experiment platform" for the dominant powers. The Cambridge Analytica Incident should be regarded as an evidence for this. Currently, more than half of the world's population actively use Facebook. It was discusses that 87 million Facebook users' data was allegedly used by Cambridge Analytica in favor of Trump to influence the US presidential election (BBC, 2018). Now, social media and political concerns co-exist. Unfortunately, there is not a coping mechanisms to guarantee free choice and protect users from such confidential initiatives that aim to influence the will of users. 
Likewise, the only option offered to users is to improve their privacy settings and secure social media use skills. The individuals are left open to exploitation whenever they are not vigilant. Therefore, informational supranationalism does not promise eternal peace among the users and communities. It is no problem for it to establish a structure that wants to know even what people want to know. Absolute desire to know is derived from Francis Bacon's conception of " knowing is for seeing beforehand and seeing beforehand is for domination" and this desire turned into the slogan of "knowledge is power". The power that comes with knowledge serves the ideal to dominate, control and direct. The notion of the information society, led by the West, needs to be refined in terms of supranational media structuring and the construction of the ontological relationship with knowledge needs to be corrected.

\section{Conclusion: Obstacles to the Supranational Media}

The main obstacle to the supranational media organization is the existing cultural and political situation that prevents the implementation of even UN decisions. For instance, states and politicians do not want to transfer the power of the media, which they have used to manufacture the consent of people. It is possible that the UN is reluctant to constitute such a media structure. The states in the UN decision-making mechanism will at least be noncommital. This may mean giving the present conjunctural advantages to the rest of the world. Politicians of developed countries will talk about media independence and politicians of underdeveloped or undeveloped countries will want to make sure that it will not lead to a new cultural imperialism. Establishment and initiation conditions of the supranational media structure should be discussed to get rid of concerns. Artificial intelligence, global digital integration and space exploration can prepare us to give up some imperial feelings and useless selfishness for the common interests of mankind.

Among the conditions that led to the establishment of the UN there was the comprehension that world peace and life safety were perceived under danger and threat because of world wars. Today, the need for supranational media organization is more than in the 1950s. Countries with historical or conjunctural conflicts with each other may have the opportunity to empathize with each other thanks to the consciousness of being an earthperson and this consciousness is activated by neutral and uncensored publications. Inter-communal peace can actualize the possibility of co-existence.

Thanks to the instrumental nature of the media, all identities, cultures, languages and religions can be freed from the attempts to homogenize with power, such as destruction, exploitation, being forced into change, and assimilation and the heterogeneous structure containing human diversity can be revitalised. It is necessary for the UN to be psychologically and intellectually prepared to establish a supranational media organization because of the inability to decide on many issues, the difficulties in implementing the decisions taken, and the weakness of sanctions, as the five permanent members of it represent different things. This will be a much more urgent need in the near future.

In the emergence of today's democratic institutions and in the development of a free environment of thought, the role of media is priceless, the civil wars, wars, wars of information and propaganda, the triggering of the economic crises and migrations are closely related to the imposed function of the media. It has become impossible for the media, 
which is in a "win-win" relationship with the political and economic powers, to make a contribution to world peace neither with its own institutional structure nor with the present approaches to the content produced by it. It is obvious that the structural and functional role of the media should be regenerated, without being subject to censorship and it should be turned into a supranational structure's self control. In today's world where truth and fiction are so intertwined with propaganda and information due to mass communication which is poltical and economy geared towards manufactured consent, a new supranational media structure, led by the UN or as an ogranisation as UN, must be established to keep the world's people away from the power groups' movements to persuade them to protest and to convey true information to cosmopolitans.

\section{REFERENCES}

Asamoah, O. (1966). The Legal Effect of Resolutions of the General Assembly. Colum. J. Transnat'l L., 3, 210, 159, 243.

BBC. (2018, April 4). Facebook scandal "hit 87 million users". http://www.bbc.com/news/technology43649018

Bentham, J. (1970). An Introduction to the Principles of Morals and Legislation. (J. B. Hart, Dü.) London: Oxford University Press.

Boyd-Barrett. (1977). Media imperialism: towards an international framework for the analysis of media systems. Mass Communication and Society, 16-135.

CNNPR (2017). Twitter. Twitter Inc.: https://twitter.com/CNNPR/status/934559957713932290 / November 25.

De Lombaerde, P. (2008). International Integration and Societal Progress: A Critical Review of Globalisation Indicators. A Critical Review of Globalisastion Indicators, 327-331.

Einstein, A. (2002, May). Why Socialism. Monthly Review, 56-62.

Fisk, R. (2001). Al Jazeera: A bold and Original TV Station. Independent. October 11, 2001.

FCC (2018, October 1). The Federal Communications Commission. fcc.gov: https://www.fcc.gov/about-fcc/what-we-do

Hobson, J. M. (2004). The Eastern Origins of Western Civilisation. London: Press Syndicate of the University of Cambridge.

Huntington, S. P. (1993). The Clash of Civilizations. Foreign Affairs, 22-49.

Hong, Sungook. (2001) Wireless: From Marconi's Black-box to the Audion, MIT Press.

Joseph Oliver Boyd-Barret, S. X. (2008). Al-Jazeera, Phoenix Satellite Television and the Return of the State: Case Studies in Market Liberalization, Public Sphere and Media Imperialism. International Journal of Communication, 206-222 .

Kant, I. (1991). Perpetual Peace: A philosophical Sketch. Cambridge: Cambridge University Press.

Kipling, R. (2000). Poetry for Young People. (E. Gillooly), New York: Sterling Publishing.

Laetrius, D. (1895). The Lives and Opinions of Eminent Philosophers. London: George Bell and Sons.

Lippman, P. (1922). Public Opinion. New York: Harcourt.

Mahajan, R. (2002). The New Crusade. New York: Monthly Review Press. 
Martin, L. H. (2018). Studies in Hellenistic Religion. (P. Pachis, Dü.) Oregon: Cascade Books.

Massey, D. (1994). Space, Place and Gender. Minneapolis: University of Minnesota Press.

Mcluhan, H. M. (1966). Information Theory. 234.

Noam Chomsky, E. S. (1998). Manufacturing Consent: The Political Economy of the Mass Media. New York.

Noelle-Neumann, E. (1974, June 1). The Spiral of Silence a Theory of Public Opinion. Journal of Communication, 43-51.

Konyukhovskiy, P.V. (2018). Proxy Wars. Discussion Paper: School of Business \& Economics, 4, 1.

Pieterse, J. N. (1994). Globalization as Hybridization. International Sociology, 161-184.

Postman, N. (1993). Technopoly; The Surrender of Culture to Technology. New York: Vintage Books A Division of Random House, Inc. p.9

Press, T. A. (2011). Egypt Security Forces Raid Al Jazeera Office in Cairo. www.haaretz.com: https://www.haaretz.com/1.5184782 - September 29, 2011.

Robertson, A. (1957). Legal Problems of european integration. The European Political Community, $105,143$.

Said, E. (2004). The Post Colonial Studies Reader Representation and Resistance. (G. G. Bill Ashcroft, Dü.) Istanbul: Routledge.

Schramm, W. L. (1964). Mass Media and National Development: The Role of Information in the Developing Countries. Stanford University Press, 65.

Schuman, R. (1950). The Schuman Declaration. http.://www.europa.eu: https://europa.eu/europeanunion/about-eu/symbols/europe-day/schuman-declaration_en - May 9, 1950.

Tomlinson, J. (1991). Cultural Imperialism: A Critical Introduction. pp. 16-94.

Toussaint, Y. (1992). La parole électrique. Du minitel aux nouvelles "machines à communiquer. Esprit Presse, 127-139.

Trump, D. (2017). Twitter Inc.: https://twitter.com/realDonaldTrump/status/934551607596986368 / November 24, 2017.

UNESCO (1973). Declaration of Guiding Principles on the Use of Satellite Broadcasting for the Free Flow of Information, the Spread of Education, and greater Cultural Exchange. to undertake studies on the consequences which the new techniques of communication by artificial satellites might have on the achievement of UNESCO's objectives. Genev: U.N.

Warf, B. (2007). Oligopolization of Global Media and Telecommunications and Its Implications for Democracy. Ethics, Place and Environment, 89-105. 